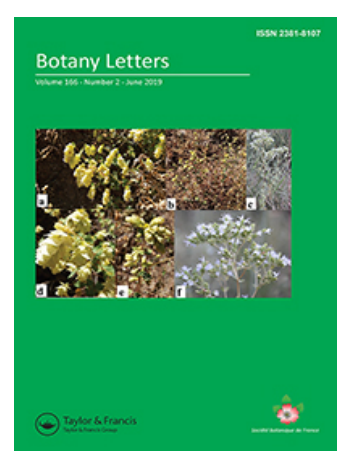

Botany Letters

ISSN: 2381-8107 (Print) 2381-8115 (Online) Journal homepage: https://www.tandfonline.com/loi/tabg21

\title{
Two sub-Antarctic and Northern Europe distributed diatom species found in a middle- mountain lake in France
}

\author{
David Heudre, Carlos E. Wetzel, Bart Van de Vijver, Laura Moreau \& Luc \\ Ector
}

To cite this article: David Heudre, Carlos E. Wetzel, Bart Van de Vijver, Laura Moreau \& Luc Ector (2019) Two sub-Antarctic and Northern Europe distributed diatom species found in a middlemountain lake in France, Botany Letters, 166:2, 212-220, DOI: 10.1080/23818107.2019.1584864

To link to this article: https://doi.org/10.1080/23818107.2019.1584864

曲 Published online: 21 Mar 2019.

Submit your article to this journal ๘

Џll Article views: 104

Q View related articles $\sqsubset$

View Crossmark data $₫$

Citing articles: 1 View citing articles 


\title{
Two sub-Antarctic and Northern Europe distributed diatom species found in a middle-mountain lake in France
}

\author{
David Heudrea, Carlos E. Wetzel $\mathbb{D}^{\mathrm{b}}$, Bart Van de Vijver $\mathbb{D}^{\mathrm{c}, \mathrm{d}}$, Laura Moreau a and Luc Ector $\mathbb{D}^{\mathrm{b}}$

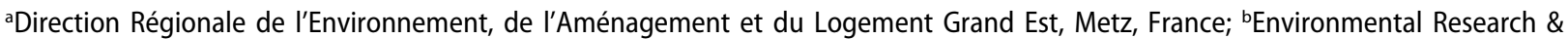 \\ Innovation (ERIN) Department, Luxembourg Institute of Science and Technology (LIST), Belvaux, Grand-Duchy of Luxembourg; \\ 'Research Department, Meise Botanic Garden, Meise, Belgium; 'Department of Biology, University of Antwerp, Wilrijk, Belgium
}

ABSTRACT

During a survey of the diatom flora of Longemer Lake (Xonrupt-Longemer, Vosges, France), two species with an unusual biogeographical distribution were observed. Psammothidium abundans, previously considered being a sub-Antarctic endemic but today also found in rivers in Sweden, Ireland and the UK, and Achnanthidium sublineare, up to now confined to northern Europe, were identified. These are the first records of these rare diatom species in France (A. sublineare) and in a European lake ( $P$. abundans). Since there are only a few illustrations of these two species in the literature, both populations are illustrated using light and scanning electron microscopy in order to provide a detailed morphological account. Details on their actual biogeographical distribution are added.
ARTICLE HISTORY

Received 29 November 2018 Accepted 1 February 2019

KEYWORDS

Achnanthidium sublineare; Psammothidium abundans; diatoms; France; lake; Vosges

\section{Introduction}

Our understanding of the biogeography of freshwater diatoms has undergone drastic changes during the past 15 years. For a long time, the biogeography of diatoms was only poorly known (Mann 1999), leading to a large number of hypotheses and speculations (Finlay 2002; Martiny et al. 2006) concerning their cosmopolitan distribution. The endemic or ubiquitous feature of their distribution was often difficult to ascertain (Vanormelingen, Verleyen, and Vyverman 2008), frequently influenced by an incorrect assessment of their diversity due to taxonomic drift and force-fitting (Tyler 1996). Moreover, the species concept within the Bacillariophyta is complex to delineate (Mann 1999). Taxa are often split based on small differences in the morphology of their frustules, lacking a full understanding of phenotypical variations (Cox 1995). Furthermore, the diatom life cycle following asexual reproduction leads to a broad size range, often inducing pronounced morphological variation (Round, Crawford, and Mann 1990).

Uniformity and identification accuracy across a national territory, a continent, or even worldwide is linked to the operators' capacity to access relevant literature for the area under survey. Typically, the visibility of European floristic guidebooks across the globe enhanced the idea that a lot of (occasionally locally endemic) taxa can be considered being widespread by "force-fitting" these taxa into European or North American names (Tyler 1996; Kociolek and Spaulding 2000). The development of diatom-based methods for monitoring water quality increases the sampling effort, especially in previously overlooked waterbodies: this tends to widen the species known distribution to new environments (Van de Vijver et al. 2008b). Moreover, the human-mediated introductions of exotic species in a growing number of areas complicates our understanding of the geographical distribution and ecology of certain taxa (Coste and Ector 2000).

Sellaphora archibaldii (J.C.Taylor \& Lange-Bertalot) Ács, C.E.Wetzel \& Ector can be considered as a good example of a purported endemic species (Ács et al. 2017). Some other taxa were overlooked due to a too wide species concept (Mann and Droop 1996) and are now distinguished as separate (often newly described) species. For example, Achnanthidium hoffmannii Van de Vijver, Ector, A.Mertens \& Jarlman, was originally described from a Swedish river (Van de Vijver et al. 2011b), but concealed for a long time in the Achnanthidium minutissimum (Kützing) Czarnecki complex and is now regularly observed in several siliceous bedrock rivers across France (Ector et al. 2015; Peeters and Ector 2018). Finally, it is still difficult to ascertain the distribution of a species by bibliographical means as most checklists do not provide illustrations of the taxa (Mann and Droop 1996) and researchers not infrequently apply the same name to different species, but also occasionally different names to the same species (Mann and Vanormelingen 2013).

The purpose of this paper is to illustrate two species, originally thought to be restricted either to subAntarctic or Northern Europe habitats, which were

CONTACT David Heudre david.heudre@developpement-durable.gouv.fr $\Theta$ Direction Régionale de l'Environnement, de l'Aménagement et du Logement Grand Est, 2 rue Augustin Fresnel, CS 95038, Metz cedex 03 57071, France

(c) 2019 Société botanique de France 
identified during a floristic survey of Longemer Lake (Xonrupt-Longemer, Vosges): Psammothidium abundans (Manguin) Bukhtiyarova \& Round and Achnanthidium sublineare Van de Vijver, Jarlman \& Ector. Based on the available literature, these observations seems to represent their first published record in France and in a European lake.

\section{Material and methods}

\section{Study area}

The Longemer Lake is located in the Vosges Mountains at $736 \mathrm{~m}$ above sea level. It was formed by morainic blocks originating from the Honeck glacier. The lake, with a length of about $1950 \mathrm{~m}$ and a width of $550 \mathrm{~m}$, is crossed by the Vologne River. It has a surface area of $76 \mathrm{ha}$, a maximum depth of around $30 \mathrm{~m}$ and a mean depth of $14.2 \mathrm{~m}$. It has a capacity of $10^{7} \mathrm{~m}^{3}$ and a mean retention time of eight months (Centre Technique du Génie Rural des Eaux et Forêts 1979; Collas 2011, 2016). It is the second lake of natural origin in the Vosges Mountains in terms of size and capacity. The substratum is essentially constituted of the impermeable crystalline (granite) and cristallophylian (gneiss) rocks. Because of the chemical nature of the bedrocks, the water is circumneutral to slightly acidic. It is an oligotrophic lake, with low temperature and well oxygenated water. There are several activities on the lake such as fishing, swimming and non-motorised nautical activities (sailing or canoeing). Maps showing the location and hydrosystem of Longemer Lake can be found in Heudre et al. (2017, fig. 1, 2018, fig. 1).

\section{Processing and observations}

The samples were collected according to the French survey protocol for benthic diatoms in lakes (Institut national de recherche en sciences et technologies 2013). They are collected at the sampling sites following AFNOR (2010). In the Longemer Lake there are three sites $\left(6^{\circ} 57^{\prime} 15^{\prime \prime}\right.$ E $48^{\circ} 4^{\prime} 14^{\prime \prime} \mathrm{N}$; $6^{\circ} 57^{\prime} 28^{\prime \prime}$ E $48^{\circ} 3^{\prime} 54^{\prime \prime} \mathrm{N} ; 6^{\circ}$ $56^{\prime} 47^{\prime \prime} \mathrm{E} 48^{\circ} 4^{\prime} 23^{\prime \prime} \mathrm{N}$ ), which were inspected on
12 July 2017. As no suitable macrophytes were available on those sites, diatoms were sampled only from hard mineral substrates.

Diatom slides were made following the French diatom protocol (AFNOR 2016). The samples were treated by oxidation with hot $37 \%$ hydrogen peroxide $\left(\mathrm{H}_{2} \mathrm{O}_{2}\right)$ and hydrochloric acid $(\mathrm{HCl})$, and rinsed three times with deionised water. For light microscopy (LM) observations, cleaned diatoms were mounted with Naphrax ${ }^{\circ}$. LM was performed with an OLYMPUS BX53 microscope using a $\times 100$ oil immersion objective and a Jenoptik ProgRes Speed XT3 camera. For scanning electron microscopy (SEM), parts of the oxidised suspensions were filtered with additional deionised water through a $3-\mu \mathrm{m}$ Isopore ${ }^{\mathrm{mm}}$ polycarbonate membrane filter (Merck Millipore). Filters were mounted on aluminium stubs and coated with platinum using a Modular High Vacuum Coating System BAL-TEC MED 020 (BAL-TEC AG, Balzers, Liechtenstein). An ultra-high-resolution analytical field emission (FE) scanning electron microscope, Hitachi SU-70 (Hitachi High-Technologies Corporation, Japan), operated at $5 \mathrm{kV}$ and $10 \mathrm{~mm}$ distance, was used for the analysis. SEM images were taken using the lower (SE-L) detector signal and a tilting of up to $28^{\circ}$. Micrographs were digitally manipulated and plates containing light and scanning electron microscopy images were created using CorelDraw $\mathrm{X}^{\circ}$.

Physical and chemical data (Table 1) were taken from the "Système d'Information sur l'Eau RhinMeuse (S.I.E.R.M.)" (http://www.rhin-meuse.eau france.fr/). The presented data are related to samples taken in the euphotic zone at the deepest point of the Longemer Lake on 27 July 2017.

\section{Results}

Division Bacillariophyta

Class Bacillariophyceae

Subclass Bacillariophycidae

Order Achnanthales

Family Achnanthidiaceae

Genus Psammothidium

Table 1. Values of physical and chemical parameters from Longemer Lake on 27 July 2017. DOC: Dissolved Organic Carbon; COD: Chemical Oxygen Demand; $\mathrm{BOD}_{5}$ : Biochemical Oxygen Demand after five days.

\begin{tabular}{|c|c|c|c|}
\hline & Longemer Lake & & Longemer Lake \\
\hline $\mathrm{NH}_{4}^{+}\left(\mathrm{mg} . \mathrm{I}^{-1}\right)$ & 0.01 & Pheopigments $\left(\mu \mathrm{g} . \mathrm{I}^{-1}\right.$ ) & 1 \\
\hline $\mathrm{NO}_{2}^{-}\left(\mathrm{mg} \cdot \mathrm{I}^{-1}\right)$ & 0.01 & $\mathrm{Ca}^{2+}\left(\mathrm{mg} . \mathrm{I}^{-1}\right)$ & 2.9 \\
\hline $\mathrm{NO}_{3}^{-}\left(\mathrm{mg} \cdot \mathrm{I}^{-1}\right)$ & 0.6 & $\mathrm{Cl}^{-}\left(\mathrm{mg} . .^{-1}\right)$ & 18 \\
\hline Kjeldhal Nitrogen (mg..$^{-1}$ ) & 0.5 & $\mathrm{Mg}^{2+}\left(\mathrm{mg} . \mathrm{I}^{-1}\right)$ & 0.88 \\
\hline Total Nitrogen (mg.l ${ }^{-1}$ ) & 0.13 & $\mathrm{~K}^{+}\left(\mathrm{mg} . \mathrm{I}^{-1}\right)$ & 0.3 \\
\hline $\mathrm{PO}_{4}^{3-}\left(\mathrm{mg} . \mathrm{I}^{-1}\right)$ & 0.01 & $\mathrm{SiO}_{2}\left(\mathrm{mg} \cdot \mathrm{I}^{-1}\right)$ & 2.7 \\
\hline Total phosphorus (mg. $\left.\right|^{-1}$ ) & 0.01 & $\mathrm{Na}^{+}\left(\mathrm{mg} . \mathrm{I}^{-1}\right)$ & 12.5 \\
\hline $\mathrm{SO}_{4}^{2-}\left(\mathrm{mg} . \mathrm{I}^{-1}\right)$ & 2.8 & Conductivity $\left(\mu \mathrm{S} . \mathrm{cm}^{-1}\right)$ & 88 \\
\hline $\mathrm{DOC}\left(\mathrm{mg} . \mathrm{I}^{-1}\right)^{\prime}$ & 1.7 & Suspended Matter (mg. $\left.\right|^{-1}$ ) & 2 \\
\hline $\operatorname{COD}\left(\mathrm{mg} . \mathrm{I}^{-1}\right)$ & 20 & $\mathrm{pH}$ & 7.1 \\
\hline $\mathrm{BOD}_{5}\left(\mathrm{mg} \cdot \mathrm{I}^{-1}\right)$ & 0.9 & Dissolved Oxygen (mg. ${ }^{-1}$ ) & 9.9 \\
\hline Chlorophyll $a\left(\mu \mathrm{g} . \mathrm{I}^{-1}\right)$ & 3 & Dissolved Oxygen saturation (\%) & 88 \\
\hline
\end{tabular}


Psammothidium abundans (Figures 1-16) has been found in two samples from Longemer Lake occurring in low relative abundance (maximum of $4 \%$ of the total valve count).

\section{Morphology}

Valves linear, usually slightly swollen in the middle part, with broadly rounded, only weakly protracted apices. Length 10.0-12.5 $\mu \mathrm{m}$, width 3.5-4.0 $\mu \mathrm{m}$. Raphe valve with a very narrow, linear axial area. Raphe filiform (Figure 13). Central area rectangular, bordered by shortened striae, the latter occasionally absent (Figures 2 and 12). Rapheless valve with a slightly lanceolate axial area, widening to an enlarged central area (Figures 6-8, 14 and 16). Transapical striae radiate throughout, 28-32 in $10 \mu \mathrm{m}$, a little more spaced in the valve middle. Areolae not visible in LM. Areolae rounded, often becoming transapically elongated to slit-like near the valve margin and near the central area (Figures 13-16). Small areolae terminating the striae on the valve face eventually present (Figure 14).

\section{Genus Achnanthidium}

Achnanthidium sublineare (Figures 17-50) was present in all three samples, with a relatively high abundance in two of them (with a maximum of $25.5 \%)$.

\section{Morphology}

Raphe valves strictly linear. Rapheless valves narrowly lanceolate. Apices acutely rounded, never rostrate, protracted nor capitate. Length 6.0-19.0 $\mu \mathrm{m}$, width $1.3-2.0 \mu \mathrm{m}$. Axial area narrows near the apices, lanceolate, widening towards the central area (Figures 47-50). Central area of the raphe valves formed by a rectangular fascia (Figures 27-30 and 45-48) whereas central area almost absent in the rapheless valves (Figures 31-33, 49 and 50). Transapical striae radiate throughout the entire valve, more strongly radiate and less spaced towards the apices, 32-33 in $10 \mu \mathrm{m}$. One, rarely two, rounded areolae present near the raphe and one areola slit-like near the valve margin. At the apices, all areolae rounded (Figures 47-50).

\section{Discussion}

Achnanthes abundans Manguin was originally described together with its var. elliptica from a sample collected on Iles Kerguelen, located in the southern Indian Ocean (Bourrelly and Manguin 1954, 19). Larson (1974), Le Cohu and Maillard (1983), Van de Vijver et al. (1998) and Gremmen et al. (2007) observed P. abundans on different localities on Iles Kerguelen. Le Cohu and Maillard (1983) amended the diagnosis of the species, including the variety elliptica within the nominate form
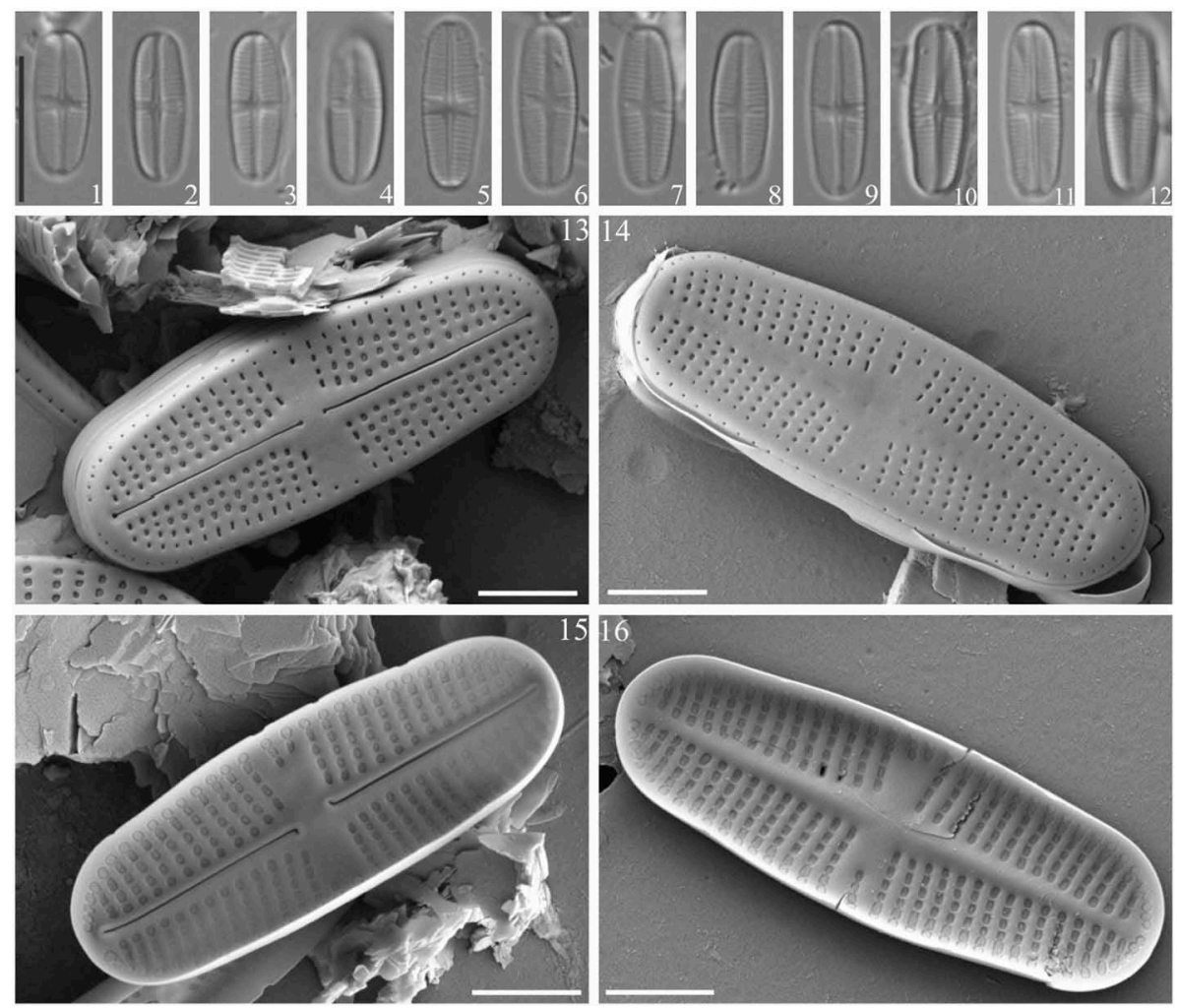

Figures 1-16. Psammothidium abundans (material from Longemer Lake at Xonrupt-Longemer). 1-12. LM valve views. Scale bar $=10 \mu \mathrm{m}$. 13-16. SEM views. 13. Raphe valve in external view. 14. Rapheless valve in external view. 15. Raphe valve in internal view. 16. Rapheless valve in internal view. Scale bar $=2 \mu \mathrm{m}$. 

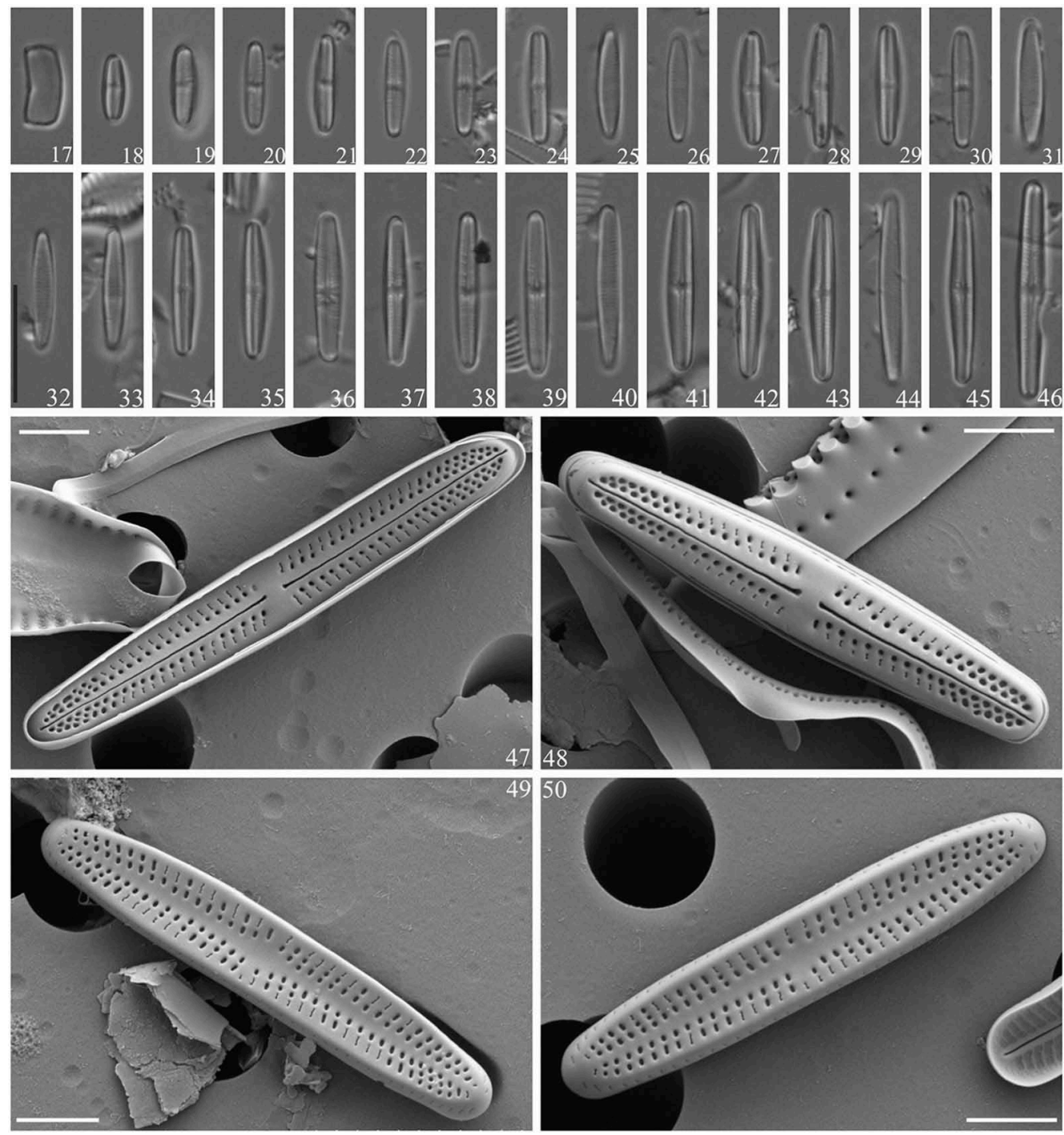

Figures 17-50. Achnanthidium sublineare (material from Longemer Lake at Xonrupt-Longemer). 17-46. LM girdle (17) and valve (18-46) views. Scale bar $=10 \mu \mathrm{m} .47-50$. SEM views. 47-48. Raphe valve in external view. 49-50. Rapheless valve in external view.

as the separation was only based on valve outline lacking a thorough analysis of the entire cell cycle. In 1996, Bukhtiyarova and Round transferred A. abundans to the genus Psammothidium.

Psammothidium abundans is widespread in the Antarctic region as can be seen by the numerous records in Kellogg and Kellogg (2002). Most records were reported from the sub-Antarctic region (McBride, Selkirk, and Adamson 1999; Van de Vijver and Beyens 1999; Van de Vijver, Frenot, and Beyens 2002; Van de Vijver et al. 2004; Van de Vijver and Gremmen 2006; Van de Vijver, Gremmen, and Smith 2008a; Saunders, Hodgson, and McMinn 2009; Chattová, Lebouvier, and Van de Vijver 2014) but there are also records from the Maritime and Continental Antarctic regions (Oppenheim 1990, 1994; Schmidt, Mausbacher, and Müller 1990; Roberts and McMinn 1999; Hodgson, Vyverman, and Sabbe 2001; Sabbe et al. 2003, 2004; Hodgson et al. 2005, 2006; Roberts et al. 2006; Kopalová and Van de Vijver 2013; Sterken et al. 2015; Zidarova,
Kopalová, and Van de Vijver 2016; John 2018). Besides these numerous Antarctic records, the species was found in some neighbouring localities such as Easter Island, South Africa, southern Australia and southern Argentina (Cocquyt 1991; Dumont et al. 1998; Maidana 2000; Sonneman et al. 2001; Flower 2005; Newall and Walsh 2005; Van de Vijver et al. 2008b; Borromei et al. 2010; Harding and Taylor 2014; García and Maidana 2015). In the Northern Hemisphere only a few records exist from rivers and brooks in Sweden, the United Kingdom and Ireland (Lange-Bertalot and Krammer 1989; Bukhtiyarova and Round 1996; Van de Vijver et al. 2008b). Figure 51 shows a world distribution map based on all previously quoted references. Psammothidium abundans is mainly found in unpolluted environments such as acidic freshwater lakes and ponds with low conductivity, but also in wet mosses and soils (Le Cohu 2005). It is probably more widespread, as our knowledge of its distribution was considerably widened during the last few decades. 
The population of Psammothidium abundans from Longemer Lake fits into the valve dimensions and characteristics of the type population as shown in Bourrelly and Manguin (1954) and Van de Vijver et al. (2008b). However, large and clearly rostro-capitated valves as shown in the Kerguelen type population (Van de Vijver et al. 2008b, figs 2, 3, 16-18) have not been observed. Moreover, the observed French specimens show a high similarity to all other known European populations (Van de Vijver et al. 2008b). The small areolae terminating the striae on the valve face shown in Bukhtiyarova and Round (1996) are present (Figures 13 and 14). The ecology seems similar to that found in the Antarctic Region: oligotrophic lakes with slightly acidic to circumneutral, cold water. Van de Vijver et al. (2008b) discussed the possible origin of this presumably Antarctic-endemic species in European waterbodies. Since morphology and ecology do not separate populations from both hemispheres, molecular-phylogenetic studies may be useful in the future to investigate possible cryptic diversity.

Achnanthidium sublineare Van de Vijver, Jarlman \& Ector was described from a sample collected in a Swedish river, Semlan, Sweden (Van de Vijver et al. 2011a). Although published already more than seven years ago, additional records of this species are lacking in the literature. Figure 51 shows the two occurrences of this species known so far.

The morphology of the Longemer population corresponds almost entirely with the original diagnosis. Achnanthidium sublineare is quite similar to Achnanthidium lineare W.Smith in light microscopy since they are only separated based on valve width, respectively $1.5-2.1 \mu \mathrm{m}$ (A. sublineare) and $2.2-2.8 \mu \mathrm{m}$ (A. lineare) (Van de Vijver et al. 2011a). However, most of the rapheless valves in the Longemer population possess clearly non-protracted apices, contrary to A. lineare that shows clearly rostrate apices and the maximum valve length differs also clearly. In scanning electronic microscopy, differences are also not very obvious. The axial area of the rapheless valve of A. sublineare (Figures 49 and 50) is narrower than observed in A. lineare (Krahn et al. 2018, figs 88-94) and the stria density differs slightly (33-35 striae per $10 \mu \mathrm{m}$ for A. sublineare vs. 28-32 for A. lineare). The striae in Achnanthidium sublineare are mainly composed of one rounded and one slit-like areola near the central area, and by usually two (Figures 48 and 49) or rarely three (Figures 47 and 50) rounded areolae towards the apices. The striae in Achnanthidium lineare on the contrary are usually composed of three areolae: two rounded and a third rounded or slit-like near the valve margins (Van de Vijver et al. 2011a). It is nevertheless possible that some individuals present striae formed by two areolae as well (Krahn et al. 2018, figs $89,93)$.

Achnanthidium sublineare might be more frequent than expected due to undersampling and underreporting in oligotrophic environments, or due to confusion with the widespread and more common A. lineare.

Studies on lakes and other lentic habitats have proven to be a valuable addition to the research on diatom biogeography and biodiversity which resulted in the description of a large number of freshwater diatoms species new to science or to a territory (e.g. Kulikovskiy et al. 2012; Potapova

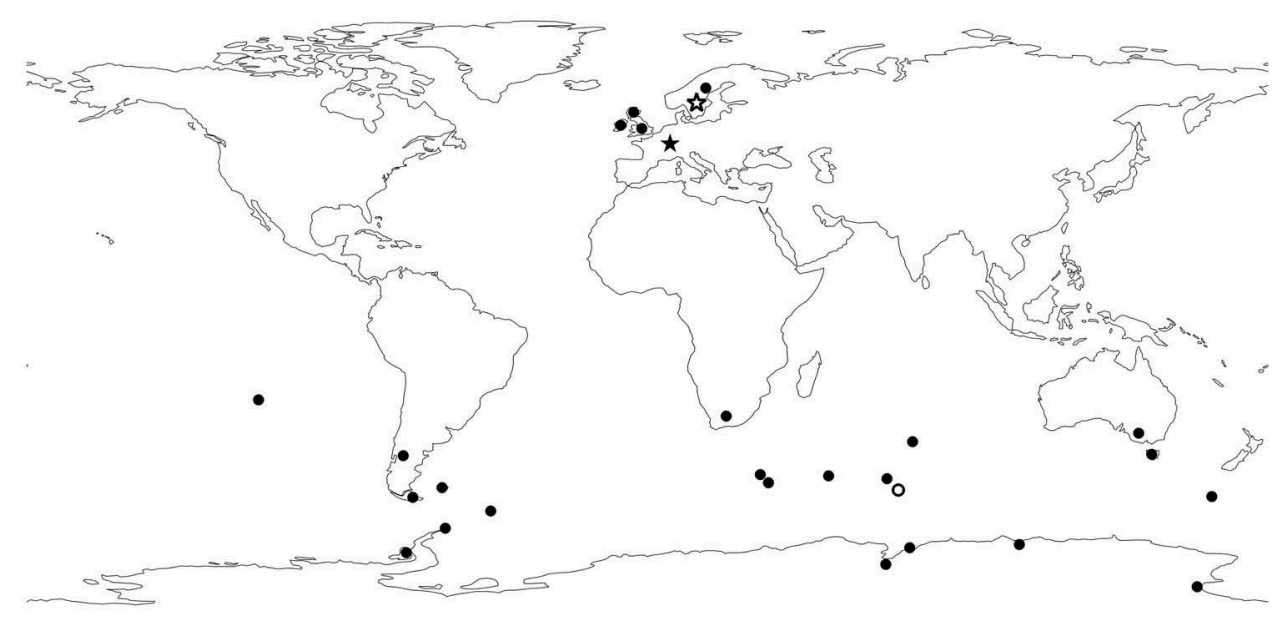

Figure 51. World geographic distribution of Psammothidium abundans and Achnanthidium sublineare. Unfilled circle indicates the type locality of Psammothidium abundans (Kerguelen Islands). Filled circles indicate bibliographical citations of Psammothidium abundans (see references in the text). White star indicates type locality of Achnanthidium sublineare (Semlan, Sweden). Black star indicates Longemer Lake (Xonrupt-Longemer, Vosges, France) where both Achnanthidium sublineare and Psammothidium abundans were found on July 2017. 
2014; Kulikovskiy, Lange-Bertalot, and Kuznetsova 2015; Rondón and Catalan 2017). This is also true in north-eastern France (Heudre et al. 2015, 2017, 2018, 2019). Increasing survey of those environments will most likely reveal their remaining unexplored biodiversity potential.

\section{Acknowledgments}

We thank two anonymous reviewers for their valuable comments that greatly improved this manuscript.

\section{Disclosure statement}

No potential conflict of interest was reported by the authors.

\section{Funding}

Funding for this research was partly provided in the framework of the project DIATOMS (LIST - Luxembourg Institute of Science and Technology).

\section{Notes on contributors}

David Heudre is a hydrobiologist at the Direction Régionale de l'Environnement, de l'Aménagement et du Logement Grand Est. He has written several articles and has been working on diatoms, aquatic plants and algae in rivers and lakes. He has been teaching on bioassessment using diatoms. Contribution: Sample collection, LM photos, plates and writing of the article.

Carlos E. Wetzel is a botanist and a researcher at the Luxembourg Institute of Science and Technology. He has written over 90 articles and he has been working on diatoms in rivers, lakes and soils. Carlos E. Wetzel has been teaching numerous training courses on diatom ecology and taxonomy designed for biologists, technicians and ecologists, contributing to the continuous improvement in the Water Framework Directive implementation in Europe. Contribution: SEM photos, discussion of results and development of the manuscript.

Bart Van de Vijver is a full-time researcher at the Meise Botanic Garden, Belgium, and a part-time professor at the University of Antwerp, Belgium. His research focuses mainly on the taxonomy, morphology and biogeography of Antarctic freshwater and terrestrial diatoms. He has been studying non-marine diatoms in various parts of the Antarctic region for more than 20 years. He has described almost 400 new taxa and revised an additional 250 taxa. Contribution: identification of diatom species, discussion of results and assistance with the writing and editing of the manuscript.

Laura Moreau is a hydrobiologist at the Direction Régionale de l'Environnement, de l'Aménagement et du Logement Grand Est. She has been working on diatoms and planktonic algae in rivers and lakes. She has been teaching on bioassessment using phytoplankton. Contribution: Sample collection, map editing and development of the manuscript.

Luc Ector is a botanist and senior researcher at the Luxembourg Institute of Science and Technology. He has written over 185 articles and has been working on diatoms in rivers, lakes and soils for the last 30 years. He was the President of the "Association des Diatomistes de Langue Française (ADLaF)", which organizes annual meetings on diatom taxonomy, ecology and related subjects. Over the last 20 years, he has been organizing and teaching numerous training courses on diatom ecology and taxonomy designed for biologists, technicians and ecologists, contributing to the continuous improvement in the Water Framework Directive implementation in Europe. Contribution: identification of diatom species, discussion of results, development, revision and editing of the manuscript.

\section{ORCID}

Carlos E. Wetzel (D) http://orcid.org/0000-0001-5330-0494 Bart Van de Vijver (D) http://orcid.org/0000-0002-62441886

Luc Ector (D) http://orcid.org/0000-0002-4573-9445

\section{References}

Ács, É., C. E. Wetzel, K. Buczkó, K. T. Kiss, K. Nagy, Z. Trábert, A. Földi, et al. 2017. "Biogeography and Morphology of a Poorly Known Sellaphora Species.” Fottea 17 (1): 57-64. doi:10.5507/fot.2016.021.

AFNOR (Association Française de Normalisation). 2010. Norme française XP T90-328 Décembre 2010. Qualité de l'eau - Échantillonnage des communautés de macrophytes en plans d'eau [French standard XP T90-328 December 2010. Water Quality - Macrophytes communities sampling in water bodies], 1-31. La Plaine Saint-Denis Cedex: Association Française de Normalisation (AFNOR).

AFNOR (Association Française de Normalisation). 2016. Norme française NF T90-354 Avril 2016. Qualité de l'eau - Échantillonnage, traitement et analyse de diatomées benthiques en cours d'eau et canaux [French standard NF T90-354 April 2016. Water quality Sampling, treatment andanalyze of benthic diatoms in streams and canals], 1-119. La Plaine Saint-Denis Cedex: Association Française de Normalisation (AFNOR).

Borromei, A. M., A. Coronato, L. G. Franzén, J. F. Ponce, J. A. L. Sáez, N. Maidana, J. Rabassa, and M. S. Candel. 2010. "Multiproxy Record of Holocene Paleoenvironmental Change, Tierra del Fuego, Argentina." Palaeogeography, Palaeoclimatology, Palaeoecology 286 (1-2): 1-16. doi:10.1016/j.palaeo.2009.11.033.

Bourrelly, P., and E. Manguin. 1954. "Contribution à la flore algale d'eau douce des Iles Kerguelen [Contribution to thefreshwater algal flora from the Kerguelen Islands]." Mémoires de l'Institut Scientifique de Madagascar, séries B 5: 7-58.

Bukhtiyarova, L., and F. E. Round. 1996. "Revision of the Genus Achnanthes sensu lato. Psammothidium, a New Genus Based on A. marginulatum.” Diatom Research 11 (1): 1-30. doi:10.1080/0269249X.1996.9705361.

Centre Technique du Génie Rural des Eaux et Forêts. 1979. ÉTude éCologique Des Lacs Des Vosges: Gérardmer et Longemer [Ecological study of the lakes from Vosges Mountains :Gérardmer and Longemer Lakes], 1-77. CTGREF.

Chattová, B., M. Lebouvier, and B. Van de Vijver. 2014. "Freshwater Diatom Communities from Ile Amsterdam (TAAF, Southern Indian Ocean)." Fottea 14 (1): 101-119. doi:10.5507/fot.2014.001. 
Cocquyt, C. 1991. "Diatoms from Easter Island.” Biologisch Jaarboek Dodonea 59: 109-124.

Collas, M. 2011. DPopulations of a Purportedescription du peuplement ichtyologique du lac de Longemer. Campagne de septembre 2010. Pêche aux filets multimailles. Norme CEN prEN 14/757 [Description of the ichthyological settlement from Longemer Lake. September 2010 Campaign. Fishing with multi-meshed nets following CEN standard prEN 14/757], 1-26. Marly: ONEMA, Dir. Nord-Est.

Collas, M. 2016. Description du peuplement ichtyologique du lac de Longemer. Campagne de septembre 2016. Pêche aux filets multimailles. Norme CEN prEN 14/757 [Description of the ichthyological settlement from Longemer Lake. September 2016 Campaign. Fishing with multi-meshed nets following CEN standard prEN 14/757], 1-27. Marly: ONEMA, Dir. Nord-Est.

Coste, M., and L. Ector. 2000. "Exotic invasive or rare diatomsin France: Main observations made during the last decades" [Diatomées invasives exotiques ou rares en France: Principales observations effectuées au cours des dernières décennies]. Systematics and Geography of Plants 70 (2): 373-400. doi:10.2307/3668651.

Cox, E. J. 1995. "Morphological Variation in Widely Distributed Diatom Taxa: Taxonomic and Ecological Implications." In Proceedings of the Thirteenth International Diatom Symposium. Maratea, Italy, 1st-7th September 1994, edited by D. Marino and M. Montresor, 335-345. Bristol: Biopress Limited.

Dumont, H. J., C. Cocquyt, M. Fontugne, M. Arnold, J. Reyss, J. Bloemendal, F. Oldfield, C. Steenbergen, H. Korthals, and B. Zeeb. 1998. "The End of Moai Quarrying and Its Effect of Lake Rano Raraku, Easter Island." Journal of Paleolimnology 20: 409-422. doi:10.1023/A:1008012720960.

Ector, L., C. E. Wetzel, M. H. Novais, and D. Guillard. 2015. Atlas des diatomées des rivières des Pays de la Loire et de la Bretagne [Atlas of diatoms from Pays de la Loireand Brittany rivers]. Vols. 1-661. Nantes: Direction Régionale de l'Environnement, de l'Aménagement et du Logement Pays de la Loire. http://www.bourgogne-franche-comte.developpementdurable.gouv.fr/publications-r2759.html.

Finlay, B. J. 2002. "Global Dispersal of Free-Living Microbial Eukaryote Species." Science 296 (5570): 1061-1063. doi:10.1126/science.1070710.

Flower, R. J. 2005. “A Taxonomic and Ecological Study of Diatoms from Freshwater Habitats in the Falkland Islands, South Atlantic." Diatom Research 20 (1): 23-96. doi:10.1080/0269249X.2005.9705620.

García, M. L., and N. I. Maidana. 2015. "Diatomeas (Bacillariophyceae) subfósiles del Brazo Blest del Lago Nahuel Huapi, Argentina." Boletín de la Sociedad Argentina de Botánica 50 (2): 123-140. doi:10.31055/ 1851.2372.v50.n2.11657.

Gremmen, N. J. M., B. Van de Vijver, Y. Frenot, and M. Lebouvier. 2007. "Distribution of Moss-Inhabiting Diatoms along an Altitudinal Gradient at sub-Antarctic Îles Kerguelen." Antarctic Science 19 (1): 17-24. doi:10.1017/S0954102007000041.

Harding, W. R., and J. C. Taylor. 2014. "Diatoms as Indicators of Historical Water Quality: A Comparison of Samples Taken in the Wemmershoek Catchment (Western Province, South Africa) in 1960 and 2008." Water SA 40 (4): 601-606. doi:10.4314/wsa.v40i4.4.

Heudre, D., C. E. Wetzel, L. Moreau, and L. Ector. 2017. "Diatoms of Gérardmer Lake (Vosges, France)." Nova
Hedwigia, Beihefte 146: 253-277. doi:10.1127/1438-9134/ 2017/253.

Heudre, D., C. E. Wetzel, L. Moreau, and L. Ector. 2018. "Sellaphora davoutiana sp. nov.: A New Freshwater Diatom Species (Sellaphoraceae, Bacillariophyta) in Lakes of Northeastern France." Phytotaxa 346 (3): 269-279. doi:10.11646/phytotaxa.346.3.6.

Heudre, D., C. E. Wetzel, L. Moreau, and L. Ector. 2019. "Fragilaria drouotiana sp. nov.: A New Epiphytic Freshwater Diatom Species (Fragilariaceae, Bacillariophyta) in Lakes of Northeastern France." Algological Studies. doi:10.1127/algol_stud/2018/0310.

Heudre, D., L. Moreau, C. E. Wetzel, and L. Ector. 2015. "Discovery of Living Populations of a Purported Fossil Diatom: Aulacoseira scalaris from Two Lakes in the Vosges Mountains (France)." Cryptogamie, Algologie 36 (3): 357-368. doi:10.7872/crya/v36.iss3.2015.357.

Hodgson, D. A., E. Verleyen, A. H. Squier, K. Sabbe, B. J. Keely, K. M. Saunders, and W. Vyverman. 2006. "Interglacial Environments of Coastal East Antarctica: Comparison of MIS 1 (Holocene) and MIS 5e (Last Interglacial) Lake-Sediment Records." Quaternary Science Reviews 25 (1-2): 179-197. doi:10.1016/j. quascirev.2005.03.004.

Hodgson, D. A., E. Verleyen, K. Sabbe, A. H. Squier, B. J. Keely, M. J. Leng, K. M. Saunders, and W. Vyverman. 2005. "Late Quaternary Climate-Driven Environmental Change in the Larsemann Hills, East Antarctica, Multi-Proxy Evidence from a Lake Sediment Core." Quaternary Research 64 (1): 83-99. doi:10.1016/j.yqres.2005.04.002.

Hodgson, D. A., W. Vyverman, and K. Sabbe. 2001. "Limnology and Biology of Saline Lakes in the Rauer Islands, Eastern Antarctica." Antarctic Science 13 (3): 255-270. doi:10.1017/S0954102001000372.

Institut national de recherche en sciences et technologies. 2013. Mise en ceuvre de la Directive Cadre Européenne sur l'eau pour les plans d'eau. Echantillonnage des communautés de phytobenthos en plans d'eau [Implementation of the European Water Framework Directive for water bodies. Sampling of phytobenthos communities in water bodies], 1-8. Cestas: Irstea, Unité de recherche REBX.

John, J. 2018. The Diatom Flora of Australia. Volume 2. Diatoms from Tasmania: Taxonomy and Biogeography, 656. Schmitten - Oberreifenberg: Koeltz Botanical Books.

Kellogg, T. B., and D. E. Kellogg. 2002. "Non-Marine and Littoral Diatoms from Antarctic and Subantarctic Regions. Distribution and Updated Taxonomy." Diatom Monographs 1: 1-795.

Kociolek, J. P., and S. A. Spaulding. 2000. "Freshwater Diatom Biogeography.” Nova Hedwigia 71 (1-2): 223-241.

Kopalová, K., and B. Van de Vijver. 2013. "Structure and Ecology of Freshwater Benthic Diatom Communities from Byers Peninsula, Livingston Island, South Shetland Islands." Antarctic Science 25 (2): 239-253. doi:10.1017/ S0954102012000764.

Krahn, K. J., C. E. Wetzel, L. Ector, and A. Schwalb. 2018. "Achnanthidium neotropicum sp. nov., A New Freshwater Diatom from Lake Apastepeque in El Salvador (Central America)." Phytotaxa 382 (1): 89-101. doi:10.11646/ phytotaxa.382.1.4.

Kulikovskiy, M. S., H. Lange-Bertalot, D. Metzeltin, and A. Witkowski. 2012. "Lake Baikal: Hotspot of Endemic Diatoms I.” Iconographia Diatomologica 23: 1-608.

Kulikovskiy, M. S., H. Lange-Bertalot, and I. V. Kuznetsova. 2015. "Lake Baikal: Hotspot of Endemic Diatoms I." Iconographia Diatomologica 26: 1-656. 
Lange-Bertalot, H., and K. Krammer. 1989. "Achnanthes, a monograph of the genus with definition of the genus Cocconeis and supplements to the Naviculaceae. "[Achnanthes eine Monographie der Gattung mit Definition der Gattung Cocconeis und Nachträgen zu den Naviculaceae]. Bibliotheca Diatomologica 18: 1-393.

Larson, D. D. 1974. "Paleoecological Investigations of Diatoms in a Core from Kerguelen Islands, Southeast Indian Ocean." Institute of Polar Studies Report No. 50, 1-61. Ohio: Ohio State University Research Foundation Columbus.

Le Cohu, R. 2005. "Révision des principales espèces dulçaquicoles d'Achnanthales (Bacillariophyta) des îles subantarctiques de Kerguelen [Revision of the Main Freshwater Species of Achnanthales (Bacillariophyta) from Sub-Antarctic Iles Kerguelen].” Algological Studies 116 (1): 79-114. doi:10.1127/18641318/2005/0116-0079.

Le Cohu, R., and R. Maillard. 1983. "Les diatomées monoraphidées des îles Kerguelen [The Diatoms " Monoraphidinae " in the Kerguelen Islands]." Annales de Limnologie - International Journal of Limnology 19 (3): 143-167. doi:10.1051/limn/1983018.

Maidana, N. I. 2000. "Continental Achnanthaceae (Bacillariophyceae) of Tierra del Fuego, Argentina. I“ [Achnanthaceae (Bacillariophyceae) continentales de Tierra del Fuego, Argentina. I.] Boletin de la Sociedad Argentina de Botanica 35 (1-2): 49-61.

Mann, D. G. 1999. "The Species Concept in Diatoms." Phycologia 38 (6): 437-495. doi:10.2216/i0031-8884-386-437.1.

Mann, D. G., and P. Vanormelingen. 2013. “An Inordinate Fondness? the Number, Distributions, and Origins of Diatom Species." Journal of Eukaryotic Microbiology 60 (4): 414-420. doi:10.1111/jeu.12047.

Mann, D. G., and S. J. M. Droop. 1996. "Biodiversity, Biogeography and Conservation of Diatoms." Hydrobiologia 336: 19-32. doi:10.1007/BF00010816.

Martiny, J. B. H., B. J. M. Bohannan, J. H. Brown, R. K. Colwell, J. A. Fuhrman, J. L. Green, M. C. HornerDevine, et al. 2006. "Microbial Biogeography: Putting Microorganisms on the Map." Nature Reviews Microbiology 4 (2): 102-112. doi:10.1038/nrmicro1341.

McBride, T. P., P. M. Selkirk, and D. A. Adamson. 1999. "Present and past Diatom Communities on Subantarctic Macquarie Island." In Proceedings of the Fourteenth International Diatom Symposium. Tokyo, Japan, September 2-8, 1996, edited by S. Mayama, M. Idei, and I. Koizumi, 353-366. Koenigstein: Koeltz Scientific Books.

Newall, P., and C. J. Walsh. 2005. "Response of Epilithic Diatom Assemblages to Urbanization Influences." Hydrobiologia 532: 53-67. doi:10.1007/s10750-004-9014-6.

Oppenheim, D. R. 1990. "A Preliminary Study of the Benthic Diatoms in Contrasting Lake Environments." In Antarctic Ecosystems. Ecological Change and Conservation, edited by K. R. Kerry and G. Hempel, 1-99. Vol. 9. Berlin Heidelberg: Springer-Verlag.

Oppenheim, D. R. 1994. "Taxonomic Studies of Achnanthes (Bacillariophyta) in Freshwater Maritime Antarctic Lakes." Canadian Journal of Botany 72 (12): 1735-1748. doi:10.1139/b94-214.

Peeters, V., and L. Ector. 2018. Atlas des diatomées des cours d'eau du territoire bourguignon. Volume 2: Monoraphidées, Brachyraphidées, 271. [Atlas of diatoms from the Burgundy territory rivers. Volume 2: Monoraphids, Brachyraphids, 271]. Dijon: Direction
Régionale de l'Environnement, de l'Aménagement et du Logement Bourgogne-Franche-Comté. http://www. bourgogne-franche-comte.developpement-durable.gouv. fr/publications-r2759.html.

Potapova, M. 2014. "Diatoms of Bering Island, Kamchatka, Russia.” Nova Hedwigia 143: 63-102. doi:10.1127/14389134/2014/004.

Roberts, D., and A. McMinn. 1999. "Diatoms of the Saline Lakes of the Vestfold Hills, Antarctica." Bibliotheca Diatomologica 44: 1-82.

Roberts, D., D. A. Hodgson, A. McMinn, E. Verleyen, B. Terry, C. Corbett, and W. Vyverman. 2006. "Recent Rapid Salinity Rise in Three East Antarctic Lakes." Journal of Paleolimnology 36 (4): 385-406. doi:10.1007/ s10933-006-9010-0.

Rondón, C. A. R., and J. Catalan. 2017. "Diatom Diversity in the Lakes of the Pyrenees: An Iconographic Reference." Limnetica 36 (1): 127-395. doi:10.23818/limn.36.10.

Round, F. E., R. M. Crawford, and D. G. Mann. 1990. The Diatoms: Biology \& Morphology of the Genera, 747. Cambridge: Cambridge University Press.

Sabbe, K., D. A. Hodgson, E. Verleyen, A. Taton, A. Wilmotte, K. Vanhoutte, and W. Vyverman. 2004. "Salinity, Depth and the Structure and Composition of Microbial Mats in Continental Antarctic Lakes." Freshwater Biology 49 (3): 296-319. doi:10.1111/j.13652427.2004.01186.x.

Sabbe, K., E. Verleyen, D. A. Hodgson, K. Vanhoutte, and W. Vyverman. 2003. "Benthic Diatom Flora of Freshwater and Saline Lakes in the Larsemann Hills and Rauer Islands, East Antarctica." Antarctic Science 15 (2): 227-248. doi:10.1017/S095410200300124X.

Saunders, K. M., D. A. Hodgson, and A. McMinn. 2009. "Quantitative Relationships between Benthic Diatom Assemblages and Water Chemistry in Macquarie Island Lakes and Their Potential for Reconstructing past Environmental Changes." Antarctic Science 21 (1): 35-49. doi:10.1017/S0954102008001442.

Schmidt, R., R. Mausbacher, and J. Müller. 1990. "Holocene Diatom Flora and Stratigraphy from Sediment Cores of Two Antarctic Lakes (King George Island)." Journal of Paleolimnology 3 (1): 55-74. doi:10.1007/BF00209300.

Sonneman, J. A., C. J. Walsh, P. F. Breen, and A. K. Sharpe. 2001. "Effects of Urbanization on Streams of the Melbourne Region, Victoria, Australia. II. Benthic Diatom Communities." Freshwater Biology 46 (4): 553-565. doi:10.1046/j.1365-2427.2001.00689.x.

Sterken, M., E. Verleyen, V. J. Jones, D. A. Hodgson, W. Vyverman, K. Sabbe, and B. Van de Vijver. 2015. "An Illustrated and Annotated Checklist of Freshwater Diatoms (Bacillariophyta) from Livingston, Signy and Beak Island (Maritime Antarctic Region)." Plant Ecology and Evolution 148 (3): 431-455. doi:10.5091/plecevo.2015.1103.

Tyler, P. A. 1996. "Endemism in Freshwater Algae with Special Reference to the Australian Region." Hydrobiologia 336 (1-3): 127-135. doi:10.1007/BF00010826.

Van de Vijver, B., A. Jarlman, H. Lange-Bertalot, A. Mertens, M. de Haan, and L. Ector. 2011b. "Four New European Achnanthidium Species (Bacillariophyceae)." Algological Studies 136-137: 193-210. doi:10.1127/1864-1318/2011/ 0136-0193.

Van de Vijver, B., and L. Beyens. 1999. "Freshwater Diatoms from Ile de la Possession (Crozet Archipelago, sub-Antarctica): An Ecological Assessment." Polar Biology 22 (3): 178-188. doi:10.1007/s003000050408.

Van de Vijver, B., L. Beyens, J. C. Gloaguen, and Y. Frenot. 1998. "The diatom flora of some Holocene peatbog 
sediments from Kerguelen Islands." [La flore diatomique de quelques sédiments tourbeux holocènes des îles Kerguelen.] Annales de Limnologie 34 (1): 3-11. doi:10.1051/limn/1998005.

Van de Vijver, B., L. Beyens, S. Vincke, and N. J. Gremmen. 2004. "Moss-Inhabiting Diatom Communities from Heard Island, sub-Antarctic." Polar Biology 27 (9): 532-543. doi:10.1007/s00300-004-0629-x.

Van de Vijver, B., L. Ector, M. E. Beltrami, M. de Haan, E. Falasco, D. Hlúbiková, A. Jarlman, M. Kelly, M. H. Novais, and A. Z. Wojtal. 2011a. "A Critical Analysis of the Type Material of Achnanthidium lineare W. Sm. (Bacillariophyceae)." Algological Studies 136-137: 167-191. doi:10.1127/1864-1318/2011/0136-0167.

Van de Vijver, B., M. Kelly, S. Blanco, A. Jarlman, and L. Ector. 2008b. "The Unmasking of a sub-Antarctic Endemic: Psammothidium abundans (Manguin) Bukhtiyarova et Round in European Rivers." Diatom Research 23 (1): 233-242. doi:10.1080/0269249X.2008.9705749.
Van de Vijver, B., and N. Gremmen. 2006. "Three New Moss-Inhabiting Diatom Species from sub-Antarctic Marion Island." Diatom Research 21 (2): 427-439. doi:10.1080/0269249X.2006.9705680.

Van de Vijver, B., N. Gremmen, and V. Smith. 2008a. "Diatom Communities from the sub-Antarctic Prince Edward Islands: Diversity and Distribution Patterns." Polar Biology 31 (7): 795-808. doi:10.1007/s00300-008-0418-z.

Van de Vijver, B., Y. Frenot, and L. Beyens. 2002. "Freshwater Diatoms from Ile de la Possession (Crozet Archipelago, Subantarctica)." Bibliotheca Diatomologica 46: 1-412.

Vanormelingen, P., E. Verleyen, and W. Vyverman. 2008. "The Diversity and Distribution of Diatoms: From Cosmopolitanism to Narrow Endemism." Biodiversity and Conservation 17 (2): 393-405. doi:10.1007/s10531007-9257-4.

Zidarova, R., K. Kopalová, and B. Van de Vijver. 2016. "Diatoms from the Antarctic Region: Maritime Antarctica." Iconographia Diatomologica 24: 1-504. 